
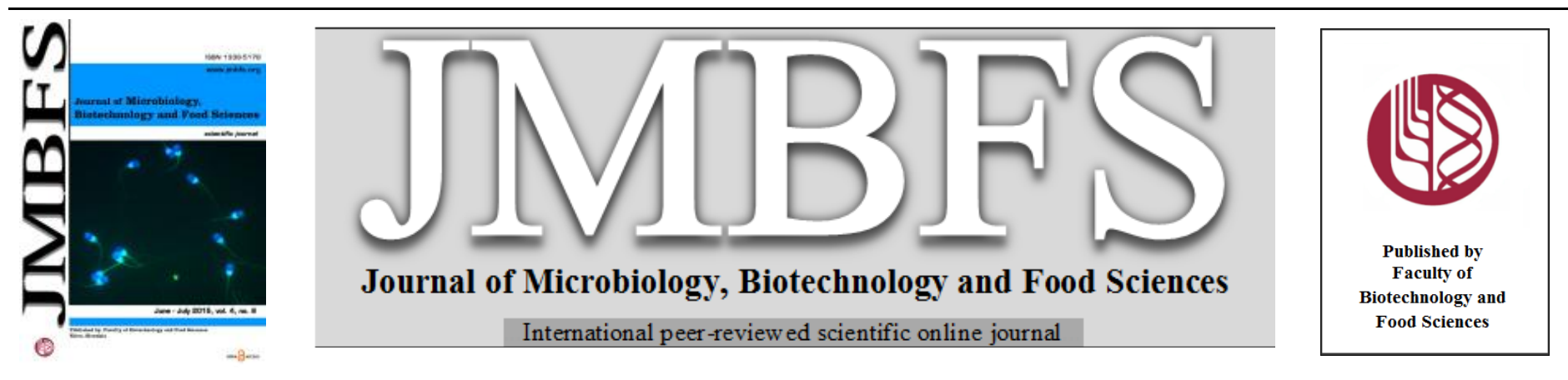

\title{
BIOCHEMICAL AND PHYLOGENETIC STUDIES OF CreD OF Corynebacterium glutamicum
}

\section{Muhammad Tausif Chaudhry* ${ }^{1}$, Raheela Chaudhry ${ }^{1}$, Shuang-Jiang Liu ${ }^{2}$}

\author{
$\operatorname{Address}(e s):$ \\ ${ }^{1}$ National Physical and Standards Laboratory, PCSIR, Islamabad, Pakistan. \\ ${ }^{2}$ Institute of Microbiology Chinese Academy of Sciences, Beijing 100101, PR China.
}

*Corresponding author: tausif_chaudhry@yahoo.com

doi: $10.15414 / j m b f s .2015 .4 .6 .478-480$

\section{ARTICLE INFO}

Received 17. 12. 2014

Revised 25. 2. 2015

Accepted 5. 3. 2015

Published 1. 6. 2015

Regular article

open 2 access

\begin{abstract}
CreD characterized as $\mathrm{Mg}^{2+}$-dependent phosphohydrolase with conserved $\mathrm{HD}$ domain was involved in 4-cresol metabolism in Corynebacterium glutamicum. Native molecular mass of $54 \mathrm{kDa}$ suggested that the biological unit is a dimer. No deoxynucleotide triphosphate triphosphohydrolase (dNTPase) activity was detected for CreD. The apparent $K_{\mathrm{m}}$ and $V_{\max }$ values for 4-nitrophenyl phosphate were $0.35 \mathrm{mM}$ and $16.23 \mu \mathrm{M} \mathrm{min}^{-1} \mathrm{mg}^{-1}$, respectively, while calculated values for $k_{\text {cat }}$ and $k_{\text {cat }} / K_{\mathrm{m}}$ were $0.4 \mathrm{~s}^{-1}$ and $1.14 \times 10^{3} \mathrm{M}$ ${ }^{1} \mathrm{~s}^{-1}$, respectively. Among thiol group inhibitors, iodoacetic acid significantly inhibited phosphohydrolase activity. Sequence identity and phylogenetic analysis suggested universal existence of CreD homologues. Involvement of HD-domain hydrolase in aromatic degradation has not been reported before.
\end{abstract}

Keywords: Corynebacterium glutamicum, 4-cresol, HD domain, metal-dependent phosphohydrolase

\section{INTRODUCTION}

In late $90 \mathrm{~s}$, a superfamily of proteins annotated as metal-dependent phosphohydrolase has been characterized as HD superfamily. As His and Asp (H...HD...D) were the highly conserved metal-coordinating residues in these proteins, phosphohydrolase activity was suggested to depend on coordination with divalent cations (Aravind and Koonin, 1998). The substrates of these proteins for nucleotidase and phosphodiesterase activities include variety of biomolecules with phosphoester bonds. Activity of HD superfamily proteins involves nucleotide metabolism, signal transduction, and other specialized functions in all the three domains of life (Proudfoot et al., 2004; Ryan et al., 2006; Worsdorfer et al., 2013). Although HD domain superfamily presently contains thousands of members, a limited number of proteins have been characterized on structural and functional basis.

Besides its industrial applications, Corynebacterium glutamicum is capable of metabolizing variety of organic compounds and a clear link between aromatic catabolism and gluconeogenesis via fructose-1,6-bisphosphate has been recognized (Qi et al., 2007). Also, three proteins, NCgl0524, NCg10525, and $\mathrm{NCg} 10527$ increased their abundance when 2-dimensional gels were compared after C. glutamicum growth on 4-cresol. $\mathrm{NCgl0525}$ and $\mathrm{NCgl0527}$ were identified to contribute towards 4-cresol metabolism (Qi et al., 2007). Recently, cre operon (ncgl0521 to $n c g l 0531$ ) involved in 4-cresol metabolism has been genetically characterized, which revealed that 4-cresol is metabolized via 4hydroxybenzoate and protocatechuate as intermediate metabolites and $\mathrm{NCgl0524}$ (CreD) was involved in conversion of 4-cresol into 4-hydroxybenzyl alcohol $(\mathbf{L i}$ et al., 2014). CreD was characterized as $\mathrm{Mg}^{2+}$-dependent phosphohydrolase with conserved HD domain. In the present report metal dependence before and after chelation, and thiol inhibition on phosphohydrolase activity of CreD were studied. In addition, kinetic parameters were determined and analysis of sequence data and phylogeny was performed.

\section{MATERIAL AND METHODS}

\section{Protein expression, purification and molecular mass determination}

CreD was expressed and initially purified as described (Li et al., 2014) and then purified by Superdex ${ }^{\mathrm{TM}} 200$ gel chromatography with Tris-HCl buffer $(20 \mathrm{mM}$, $\mathrm{pH}$ 7.5) controlled by fast protein liquid chromatography system (AKTA, GE Healthcare, UK). After ultra filtration, concentration was determined by Bradford assay according to manufacturer's instructions (Bio-Rad, Hercules, CA). Native molecular mass was estimated by size-exclusion chromatography on Superdex
200 GL column (GE Healthcare, UK) eluted with $50 \mathrm{mM}$ Tris- $\mathrm{HCl}(\mathrm{pH} 7.6)$ containing $100 \mathrm{mM} \mathrm{NaCl}$ at a flow rate of $0.4 \mathrm{ml} \mathrm{min}^{-1}$.

\section{Metal dependence of phosphohydrolase activity of CreD}

Phosphohydrolase activity was determined with 4-nitrophenyl phosphate (4-NPP) as substrate (Proudfoot et al., 2004) with divalent cations $\left(\mathrm{Ba}^{2+}, \mathrm{Ca}^{2+}, \mathrm{Co}^{2+}, \mathrm{Cu}^{2+}\right.$ $\mathrm{Mg}^{2+}, \mathrm{Mn}^{2+}, \mathrm{Ni}^{2+}$, and $\left.\mathrm{Zn}^{2+}\right)$. The reaction mixture (50 mM of CHES-K buffer (pH 8.5), $5 \mathrm{mM}$ cation, $4 \mathrm{mM}$ 4-NPP, and $1 \mu \mathrm{g}$ CreD) was incubated for 10-20 min at $37^{\circ} \mathrm{C}$ before recording $A_{410}, \lambda_{\max }$ of 4-nitrophenol product. One enzyme unit was defined as amount of $\mathrm{CreD}$ liberating $1 \mathrm{mM}$ of 4-nitrophenol per min Positive control (with CIP) and negative control (without CreD) were included and all experiments were conducted in triplicate. Non-ion-selective chelator, EDTA, was used to chelate divalent cations from CreD. The reaction mixture contained $50 \mathrm{mM}$ CHES-K buffer ( $\mathrm{pH} 8.5$ ), 1.25-8.75 $\mu \mathrm{M}$ EDTA (pH 8.5), and 1 $\mu \mathrm{g} \mathrm{CreD}$. The reaction mixture was incubated at $37^{\circ} \mathrm{C}$ for $10 \mathrm{~min}$ before addition of 4-NPP (4 mM) and further incubated at $37^{\circ} \mathrm{C}$ for $10-20 \mathrm{~min}$ before recording $A_{410}$. After chelation with EDTA $(6.25 \mathrm{mM})$, metal-dependence was determined as mentioned above. After incubation for $20 \mathrm{~min}$ at $37^{\circ} \mathrm{C}$, cation $(5 \mathrm{mM})$ was added and reaction mixture was incubated at $37^{\circ} \mathrm{C}$ for $10-20 \mathrm{~min}$. Finally, $A_{410}$ was recorded. Both positive and negative controls were run in parallel.

\section{Effect of thiol (-SH) inhibition}

The reaction mixture $(200 \mu \mathrm{l})$ contained $50 \mathrm{mM}$ CHES-K buffer $(\mathrm{pH} 8.5), 5 \mathrm{mM}$ $\mathrm{Mg}^{2+}, 1 \mu \mathrm{g} \mathrm{CreD}$ and $0.5-10 \mathrm{mM}$ of various $-\mathrm{SH}$ inhibitors (dithiothreitol, iodoacetic acid, iodoacetamide and $\mathrm{N}$-ethylmaleimide). The reaction mixture was incubated at $37{ }^{\circ} \mathrm{C}$ for $10 \mathrm{~min}$ before addition of 4-NPP $(4 \mathrm{mM})$ and further incubated for 10-20 min before recording $A_{410}$. Both positive and negative controls were included in each set of experiments.

\section{Kinetic parameters}

Kinetic parameters, half-saturation constant or Michaelis constant $\left(K_{\mathrm{m}}\right)$, maximum reaction rate $\left(V_{\max }\right)$, turnover number $\left(k_{\text {cat }}\right)$, and specificity constant $\left(k_{\text {cat }} / K_{\mathrm{m}}\right)$ were determined from Lineweaver-Burk plot. Reaction was carried out in $50 \mathrm{mM}$ CHES-K buffer (pH 8.5) with $0.5-20 \mathrm{mM}$ of $4-\mathrm{NPP}$ at $37{ }^{\circ} \mathrm{C}$ as described. All reaction rates were linear during the course of reaction. 
Hydrolase assay with deoxyribonucleotides (dNTPs) in vitro

Reaction mixture $(160 \mu \mathrm{l})$ contained $50 \mathrm{mM}$ CHES-K buffer $(\mathrm{pH} 8.5), 1 \mathrm{mM}$ substrate (dNTP), and 0.1-1.0 $\mu \mathrm{g}$ CreD. After incubation for $20-30 \mathrm{~min}$ at $37^{\circ} \mathrm{C}$, the reaction was terminated by the addition of $40 \mu \mathrm{l}$ malachite green reagent (Baykov et al. 1988), and after 5 min production of inorganic phosphate (Pi) was measured as $A_{630}$ (Proudfoot $\boldsymbol{e t}$ al., 2004). One unit of activity was defined as 1 $\mu \mathrm{M}$ of Pi produced per min.

\section{Analysis of sequence data and phylogeny}

CreD (NCg10524) sequence (Accession No. NP599785) was obtained from GenBank. Sequence comparison and similarity search was performed using BLAST (http://www.ncbi.nlm.nih.gov). Pairwise and multiple sequence alignments were made with CLUSTAL W (Aiyar, 2000). Phylogenetic analysis was conducted using neighbor-joining method based on 1000 replications employing MEGA4 (Tamura et al., 2007)

\section{RESULTS AND DISCUSSION}

Subunit molecular mass of $27 \mathrm{kDa}$ and native molecular mass of $54 \mathrm{kDa}$ suggested that the biological unit is a dimer. This result is in accordance with reports on crystal structure and biochemical characterization of HD domain superfamily proteins. For instance, YfbR of E. coli is biologically active as a dimer (Zimmerman et al., 2008), dNTPase of Enterococcus faecalis and human PDE4 (Huai et al., 2003) are biologically active as homotetramer, while dNTPase of Thermus thermophilus forms a homohexamer as a double ring of trimers (Kondo et al., 2007).

Phosphohydrolase activity profile of $\mathrm{CreD}$ with divalent cations is shown in figure $1 \mathrm{~A}$. Highest activity was achieved with $\mathrm{Ba}^{2+}, \mathrm{Ca}^{2+}$ and $\mathrm{Mg}^{2+}(6.78,6.45$ and $6.78 \mu \mathrm{M} \mathrm{min}{ }^{-1} \mathrm{mg}^{-1}$, respectively) while $\mathrm{Cu}^{2+}, \mathrm{Mn}^{2+}, \mathrm{Ni}^{2+}$, and $\mathrm{Zn}^{2+}$ did not support activity. Apparently, activity was still high in the absence of any cation that indicates coordination of some divalent cation with protein in its natural form when expressed in cells. Activity profile after chelation with EDTA is shown in figure 2. As indicated, activity gradually decreased with increasing EDTA concentration till $6.25 \mu \mathrm{M}$ where there is no further decrease. After chelation, metal dependence of CreD is shown in figure 1B. Maximum phosphohydrolase activity $\left(7.12 \mu \mathrm{M} \mathrm{min}{ }^{-1} \mathrm{mg}^{-1}\right.$ ) was achieved with $\mathrm{Mg}^{2+}$. Now activity was significantly lower with same concentrations of $\mathrm{Ba}^{2+}, \mathrm{Ca}^{2+}$, and $\mathrm{Co}^{2+}$, which was considerably high without chelation (Figure 1A). No considerable activity was observed with $\mathrm{Zn}^{2+}$ and in the absence of any cation. Phosphatase activity of SurE and $\mathrm{YjjG}$ of $E$. coli with 4-NPP is also $\mathrm{Mg}^{2+}$-dependent (Proudfoot et al., 2004) However, these results are different with those reported for YfbR and tRNA-NT of E. coli, and human PDE4 where maximum activity was achieved with $\mathrm{Co}^{2+}$, $\mathrm{Ni}^{2+}$, and $\mathrm{Zn}^{2+}$, respectively (Proudfoot et al., 2004; Yakunin et al,. 2004; Xu et al., 2000). Contrary to Kondo et al. (2007), no dNTPase activity was observed. Cysteine residues were located at five different positions in $\mathrm{CreD}$ sequence $\left(\mathrm{Cys}^{47}, \mathrm{Cys}^{85}, \mathrm{Cys}^{138}\right.$, Cys ${ }^{159}$ and $\mathrm{Cys}^{182}$ ), which contain free thiol (-SH) groups These groups might form disulfide bonds that stabilize the overall structure of protein, which in turn co-ordinates with divalent cations to confer activity. Alkylation of these groups might produce certain structural changes that resulted in partial or complete loss of activity. Figure 3 indicates that thiol groups attached to Cys residues have significant contribution towards hydrolase activity of CreD. Iodoacetic acid significantly inhibited phosphohydrolase activity $\left(0.72 \mu \mathrm{M} \mathrm{min}^{-1}\right.$ $\mathrm{mg}^{-1}$ at $1 \mathrm{mM}$ concentration) while there was no apparent effect with $10 \mathrm{mM}$ dithiotreitol. At $10 \mathrm{mM}$ concentration, activity was fairly inhibited by $N$ ethylmaleimide $\left(0.76 \mu \mathrm{M} \mathrm{min}{ }^{-1} \mathrm{mg}^{-1}\right)$ whereas only partially with iodoacetamide (3.41 $\left.\mu \mathrm{M} \mathrm{min}^{-1} \mathrm{mg}^{-1}\right)$.

A plot of $1 /[\mathrm{S}]$ vs $1 / V$ was a straight line (Lineweaver-Burk plot), where [S] and $V$ were substrate concentration $\left(\mu \mathrm{g} \mu \mathrm{l}^{-1}\right)$ and reaction rate $\left(\mu \mathrm{M} \mathrm{min} \mathrm{mg}^{-1}\right)$, respectively. The values of kinetic parameters $K_{\mathrm{m}}$ and $V_{\max }$ as indicated by the plot were $0.35 \mathrm{mM}$ and $16.23 \mu \mathrm{M} \mathrm{min} \mathrm{mg}^{-1}$, respectively. The value of $K_{\mathrm{m}}$ placed CreD into the "high $K_{\mathrm{m}}$ " (millimole range) group of phosphohydrolases. Enzyme having high $K_{\mathrm{m}}$ requires a higher concentration of substrate to achieve $V_{\max }$. Under normal conditions, enzyme activity varies with substrate concentration, which consequently controls the rate of formation of product. An example of such proteins is haloacid dehalogenase- (HAD) like superfamily protein YjjG of E. coli (Proudfoot et al., 2004). The calculated values of $k_{\text {cat }}$ and $k_{\text {cat }} / K_{\mathrm{m}}$ were $0.4 \mathrm{~s}^{-1}$ and $1.14 \times 10^{3} \mathrm{M}^{-1} \mathrm{~s}^{-1}$, respectively.

Figure 4A represents the phylogenetic relationship of CreD and related HD domain phosphohydrolases from other species. Two clusters are evident from the figure. Upper cluster consists of HD domain phosphohydrolases from aerobic, non-motile, mesophilic, Gram-positive bacteria with high $\mathrm{G}+\mathrm{C}$ content like Rhodococcus wratislaviensis $(67.0 \mathrm{~mol} \%)$, Gordonia rhizosphera $(66.8 \mathrm{~mol} \%)$, and Arthrobacter crystallopoietes $(66.6 \mathrm{~mol} \%)$. CreD belongs to this cluster with phylogenetically very close protein from $C$. efficiens YS-314 (NP737166). Lower cluster mostly contains anaerobic, mesophilic, Gram-negative bacteria of low (Emticicia oligotrophica DSM 17448, $36.9 \mathrm{~mol} \%$ ) to high (Loktanella vestfoldensis, $62.3 \mathrm{~mol} \%$ ) G+C content. Phylogenetic analysis indicates universal existence of CreD homologues.

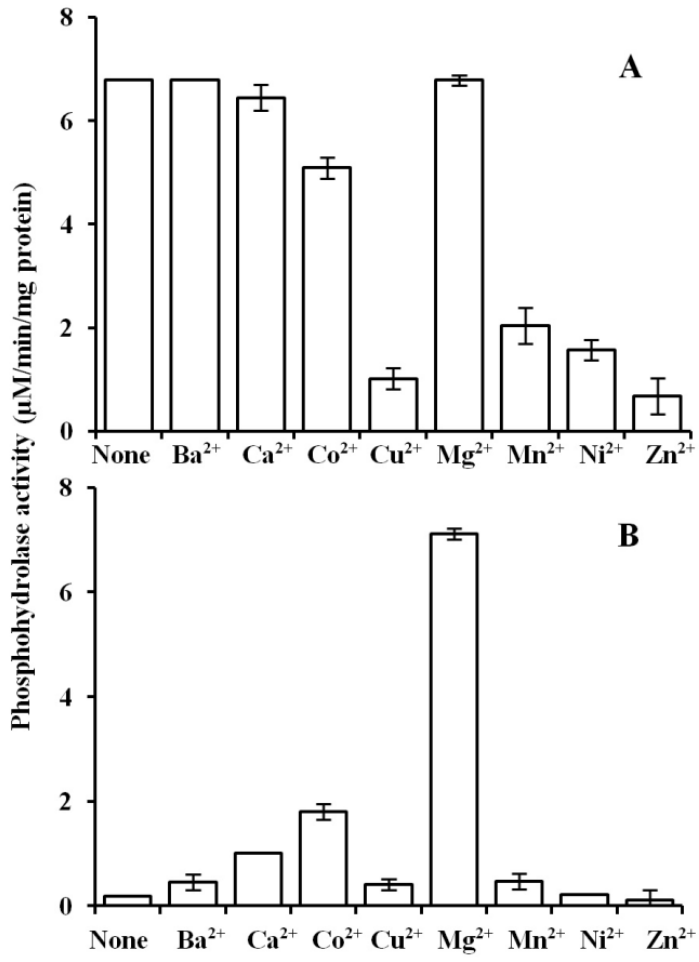

Figure 1 Metal dependence of phosphohydrolase activity of CreD against 4-NPP (A) before chelation and (B) after chelation with $6.25 \mu \mathrm{M}$ EDTA (bars represent the standard error of the mean)

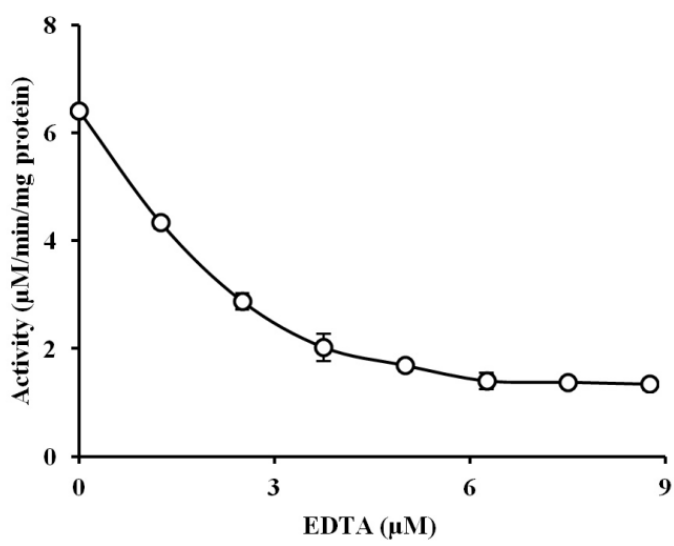

Figure 2 Effect of EDTA concentration on phosphohydrolase activity of CreD against 4-NPP (bars represent the standard error of the mean)

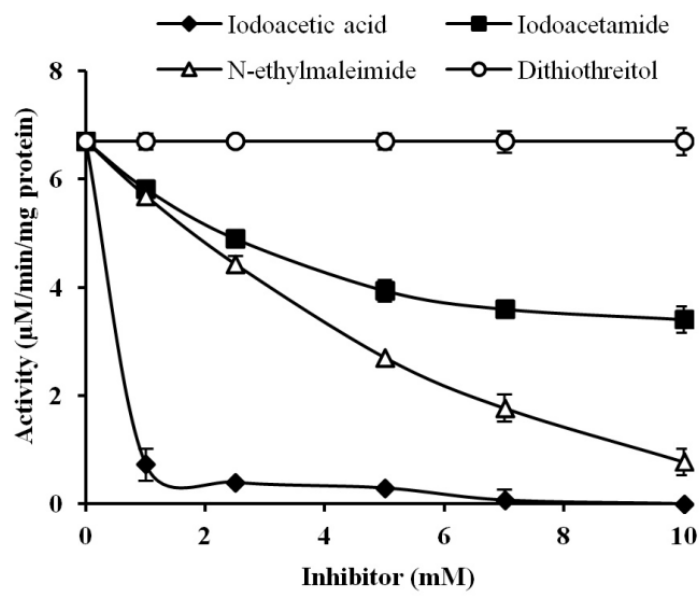

Figure 3 Effect of thiol inhibition on phosphohydrolase activity of CreD against 4-NPP (bars represent the standard error of the mean) 
Metal-coordinating conserved residues $\left(\mathrm{His}^{73}\right.$ and $\mathrm{Asp}^{183}$ ) and HD signature $\left(\mathrm{His}^{103}\right.$ and $\mathrm{Asp}^{104}$ ) located in CreD sequence are highlighted in figure 4B. Along with $\mathrm{Mg}^{2+}$-coordinating conserved residue $\left(\mathrm{Asp}^{104}\right), \mathrm{Zn}^{2+}$-chelating residues $\left(\mathrm{His}^{73}, \mathrm{His}^{103}\right.$, Asp ${ }^{104}$, and $\mathrm{Asp}^{183}$ ) are also conserved. However, phosphohydrolase activity towards 4-NPP was negligible with $\mathrm{Zn}^{2+}(0.10 \mu \mathrm{M}$ $\left.\mathrm{min}^{-1} \mathrm{mg}^{-1}\right)$ as compared to $\mathrm{Mg}^{2+}\left(7.12 \mu \mathrm{M} \mathrm{min}^{-1} \mathrm{mg}^{-1}\right.$; Figure 1B). In addition, no conserved residues or domains reported to confer signal transduction in phosphohydrolases (Galperin et al., 1999) were located in CreD.
Contribution of HD-domain proteins in nucleic acid metabolism and signal transduction is well-known for more than two decades. This report reveals that CreD of C. glutamicum, involved in 4-cresol metabolism, is a metal-dependent phosphohydrolase with conserved HD-domain. To best of our knowledge, involvement of HD-domain phosphohydrolases in aromatic compound degradation has not been reported before.
A

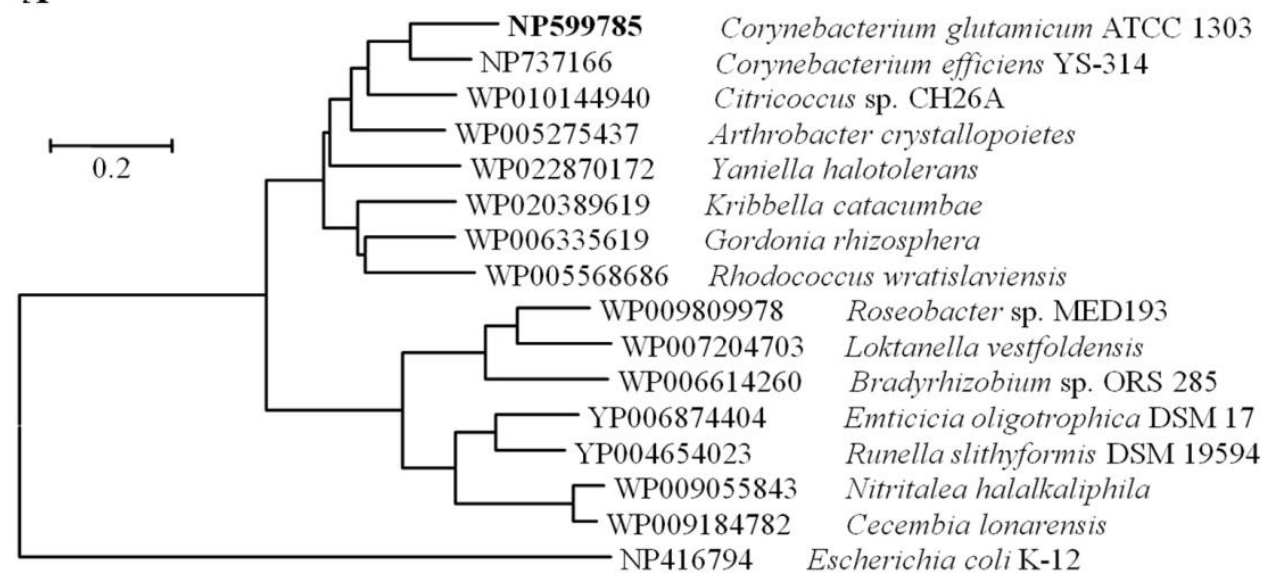

Sequence identity $(\%)$

100

78.3

66.9

66.2

58.5

53.4

56.2

52.2

32.6

31.4

32.6

31.8

32.2

31.4

31.4

7.2

B

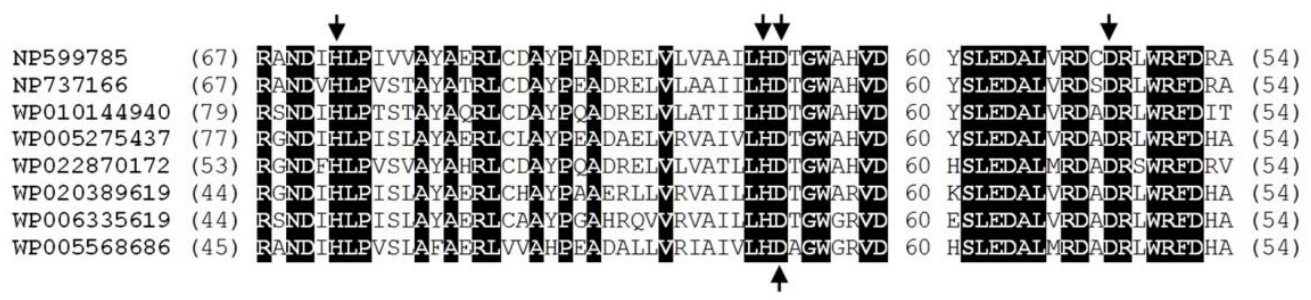

Figure 4 (A) Phylogenetic tree of metal-dependent phosphohydrolases with conserved HD domain including CreD (shown in bold). The scale bar indicates percent divergence (distance). Yfbr of E. coli (NP416794) serves as outgroup. (B) Sequence alignment of metaldependent HD domain phosphohydrolases from Gram-positive, high $\mathrm{G}+\mathrm{C}$ bacteria. Numbers within parentheses indicate number of residues between protein termini and proximal and distal aligned blocks while numbers between individual blocks indicate number of residues separating them. Highly conserved residues are highlighted in black. Arrows above the alignment show $\mathrm{Zn}^{2+}$-coordinating His and Asp residues while arrow bellow shows Asp residue that binds $\mathrm{Mg}^{2+}$.

Acknowledgments: This work was supported by grant (31200088) from the National Natural Science Foundation of China.

\section{REFERENCES}

AIYAR, A. 2000. The use of CLUSTAL W and CLUSTAL X for multiple sequence alignment. Methods in Molecular Biology, 132, 221-241. http://dx.doi.org/10.1385/1-59259-192-2:221

ARAVIND, L., KOONIN, E.V. 1998. The HD domain defines a new superfamily of metal-dependent phosphohydrolases. Trends in Biochemical Sciences, 23(12), 469-472. http://dx.doi.org/10.1016/s0968-0004(98)01293-6

BAYKOV, A.A., EVTUSHENKO, O.A., AVAEVA, S.M. 1988. A malachite green procedure for orthophosphate determination and its use in alkaline phosphatase-based enzyme immunoassay. Analytical Biochemistry, 171(2), 266270. http://dx.doi.org/10.1016/0003-2697(88)90484-8

HUAI, Q., COLICELLI, J., KE, H. 2003. The crystal structure of AMP-bound PDE4 suggests a mechanism for phosphodiesterase catalysis. Biochemistry, 42(45), 13220-13226. http://dx.doi.org/10.1021/bi034653e

KONDO, N., NAKAGAWA, N., EBIHARA, A., CHEN, L., LIU, Z.J., WANG, B.C., YOKOYAMA, S., KURAMITSU, S., MASUI, R. 2007. Structure of dNTP-inducible dNTP triphosphohydrolase: insight into broad specificity for dNTPs and triphosphohydrolase-type hydrolysis. Acta Crystallographica Section $D, 63(2), 230-239$. http://dx.doi.org/10.1107/s0907444906049262

LI, T., CHEN, X., CHAUDHRY, M.T., ZHANG, B., JIANG, C.Y., LIU, S.J. 2014. Genetic characterization of 4-cresol catabolism in Corynebacterium glutamicum. Journal of Biotechnology, 192, 355-365. http://dx.doi.org/10.1016/j.jbiotec.2014.01.017

PROUDFOOT, M., KUZNETSOVA, E., BROWN, G., RAO, N.N., KITAGAWA, M., MORI, H., SAVCHENKO, A., YAKUNIN, A.F. 2004 General enzymatic screens identify three new nucleotidases in Escherichia coli. Biochemical characterization of SurE, YfbR, and YjjG. Journal of Biological Chemistry, 279(52), 54687-54694. http://dx.doi.org/10.1074/jbc.m411023200
QI, S.W., CHAUDHRY, M.T., ZHANG, Y., MENG, B., HUANG, Y., ZHAO, K.X., POETSCH, A., JIANG, C.Y., LIU, S., LIU, S.J. 2007. Comparative proteomes of Corynebacterium glutamicum grown on aromatic compounds revealed novel proteins involved in aromatic degradation and a clear link between aromatic catabolism and gluconeogenesis via fructose-1,6$\begin{array}{llll}\text { bisphosphatase. } & \text { Proteomics, } & \text { 7(20), } & \text { 3775-3787. }\end{array}$ http://dx.doi.org/10.1002/pmic.200700481

RYAN, R.P., FOUHY, Y., LUCEY, J.F., CROSSMAN, L.C., SPIRO, S., HE, Y.W., ZHANG, L.H., HEEB, S., CAMARA, M., WILLIAMS, P., DOW, J.M. 2006. Cell-cell signaling in Xanthomonas campestris involves an HD-GYP domain protein that functions in cyclic di-GMP turnover. Proceedings of National Academy of Sciences of the USA, 103(17), 6712-6717. http://dx.doi.org/10.1073/pnas.0600345103

TAMURA, K., DUDLEY, J., NEI, M., KUMAR, S. 2007. MEGA4: Molecular Evolutionary Genetics Analysis (MEGA) software version 4.0. Molecular Biology and Evolution, 24(8), 596-599. http://dx.doi.org/10.1093/molbev/msm092

WORSDORFER, B., LINGARAJU, M., YENNAWAR, N.H., BOAL, A.K., KREBS, C., BOLLINGER, J.M. Jr., PANDELIA, M.E. 2013. Organophosphonate-degrading PhnZ reveals an emerging family of HD domain mixed-valent diiron oxygenases. Proceedings of National Academy of Sciences of the USA, 110(47), 18874-18879. http://dx.doi.org/10.1073/pnas.1315927110 XU, R.X., HASSELL, A.M., VANDERWALL, D., LAMBERT, M.H., HOLMES, W.D., LUTHER, M.A., ROCQUE, W.J., MILBURN, M.W., ZHAO, Y., KE, H., NOLTE, R.T. 2000. Atomic structure of PDE4: insights into phosphodiesterase mechanism and specificity. Science, 288, 1822-1825. http://dx.doi.org/10.1126/science.288.5472.1822

YAKUNIN, A.F., PROUDFOOT, M., KUZNETSOVA, E., SAVCHENKO, A., BROWN, G., ARROWSMITH, C.H., EDWARDS, A.M. 2004. The HD domain of the Escherichia coli tRNA nucleotidyltransferase has 2',3'-cyclic phosphodiesterase, 2'-nucleotidase, and phosphatase activities. Journal of Biological Chemistry, $\quad$ 279(35), $36819-36827$. http://dx.doi.org/10.1074/jbc.m405120200 